\title{
A Review on Rice False Smut, it's Distribution, Identification and Management Practices
}

\author{
Bhanu Dangi ${ }^{1 *}$, Saugat Khanal ${ }^{2}$ and Shubekshya Shah ${ }^{3}$ \\ ${ }^{1}$ Sahara Multipurpose Agriculture Farm, Tulsipur, Dang, Nepal \\ ${ }^{2}$ Faculty of Agriculture, Agriculture and Forestry University, Rampur, Chitwan, \\ Nepal \\ ${ }^{3}$ Institute of Agriculture and Animal Science, Tribhuvan University, Nepal \\ *Corresponding Author: Bhanu Dangi, Sahara Multipurpose Agriculture Farm, \\ Tulsipur, Dang, Nepal.
}

Received: October 27, 2020

Published: November 21, 2020

(C) All rights are reserved by Bhanu Dangi., et al.

\begin{abstract}
Rice (Oryza sativa) is the major source of food security for most of the population in the world. False smut is recently emerging as a major Rice disease which was previously considered to have a negligible impact. An ascomycetes fungus, Villosiclava virens is the pathogen that causes the False Smut disease of rice. It is found in two different stages sexual and asexual and both spores can infect the spikelet and lead to the formation of smut ball of rice grain. The disease has been reported from all across the world after being reported for the first time in Tamil Nadu by Cooke in 1878. Rice False Smut has been reported to cause $40 \%$ of the yield losses and this disease can be controlled with the proper management practices and the control approaches. The disease is found to have linked with the higher nitrogen usages and the occurrence of heavy rainfall during Reproductive stage. Preventive approaches include crop rotation, optimum nitrogen usages, selection of the resistant variety, scheduling of the crop plantation to avoid raining during sensitive stages and field preparation. While control of the disease could be done with different methods, application of fungicides Triûoxystrobin 25\%+ Tebuconazole 50\% and Propiconazole 25 EC in vitro and in vivo condition showed 100\% inhibition to growth of fungal mycelium being the most effective chemical among other contemporary fungicides. Among the different fungicides tested azoxystrobin (18.2\%) SC showed better efficacy at 0.1 per cent and enhanced the paddy yield under field condition. The study done by Raji 2016 shows significant control of the False smut using the extract of garlic, turmeric, lantana and Bael, whereas plant oils of lemon grass and cinnamon have completely inhibited the growth of U. virens. Andargie., et al. (2017) reported Antennariella placitae a bio-control agent to be effective against rice false smut (Ustilaginoidea virens) both in vitro and in vivo condition. This review aims to educate about the disease and its effective management strategies.
\end{abstract}

Keywords: False Smut; Ustilaginoidea virens; Rice Disease, Fungicides, Disease Management

\section{Abbreviations}

RFS: Rice False Smut; hg/ha: Hundred Grams Per Hectare

\section{Introduction}

Rice is widely consumed as staple food for large part of the world >s human population, especially in Asia and Africa. It is ranked in third-highest production position (rice, 741.5 million tones in 2014), worldwide after sugarcane and Maize [20]. Rice is the most important grain regarding to its human nutri- tion and caloric intake, providing more than one-fifth of the calories consumed worldwide by humans [43]. Rice security is not only an economic issue but also an important parameter to determine social and political stability [22]. Thus, significant strategies need to be made to reduce the losses due to pest and disease. Among various disease regarding the low status of rice, Rice False Smut (RFS) disease is one that is becoming the threat to both yield and grain quality. RFS was considered as the minor disease-causing negligible loss of the product, however considering its severity now in most 
of the rice growing regions, such as China, India, and USA it has brought the interest of many agriculture scientist $[9,18]$.

An ascomycetes fungus, Villosiclava virens $(\mathrm{Vv})$ is the pathogen that causes the False Smut disease of rice. It possesses both teleomorphic state producing sexual ascospores and an anamorphic state generating asexual chlamydospores). Both sexual and asexual spores can infect the rice spikelet and convert a rice grain into a ball of mycelium [47]. Pathogen causes the formation of a white fungal mass inside spikelet at its early stage which are then converted into light-yellow smut balls and with disease development smut balls changes its color to orange, then green, olive-green and eventually greenish-black. Numerous chlamydospores are present in the outer layer of mature smut balls covered by sclerotia [21]. Along with RFS balls it also causes the sterility of the nearby kernels and that causes the considerable loss in both yield and quality [16]. Similarly, RFS balls produce two types of mycotoxins (ustiloxin and ustilaginoidin) which can cause significant health hazards to both human and animals by contaminating rice grains and straws [50]. Severity of the disease is most likely to occur when rice booting and heading stages meet with periodic rainfall. However, it may vary largely depending on varieties, fields, and seasons.

\section{Trend of rice yield in Nepal}

Rice yield in Nepal fluctuates over years. It is mainly due to the attack of several pests and diseases due to which the farmers suffer from yield crisis.

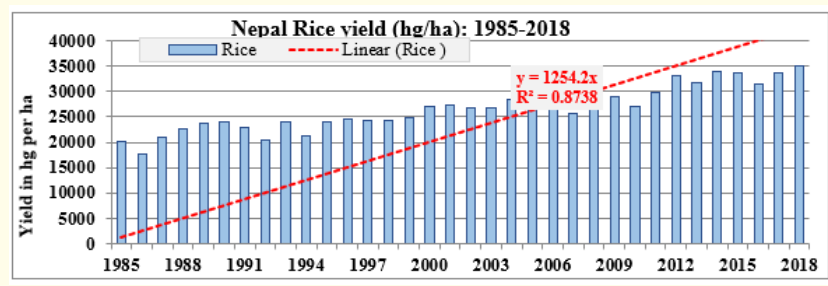

Figure 1: Rice yield in Nepal from 1985-2018.

Source: (FAOSTAT, 2020).

Figure 1 shows the total yield of Rice in Nepal in different years from 1985-2018. In 1985, rice yield was $20161 \mathrm{hg} /$ ha (hundred grams per hectare). In 2018, the significant increase in yield was attained with $35058 \mathrm{hg} / \mathrm{ha}$. However, the potential has been not achieved due to various constraints from sowing to harvesting. The popular rice diseases that are common in Nepal are mentioned in table 1.

\begin{tabular}{|c|c|c|c|}
\hline S.N & Diseases & Causative agents & Status \\
\hline \multicolumn{4}{|c|}{ Fungal } \\
\hline 1 & Blast & Pyricuaria oryzae & Major \\
\hline 2 & Sheath blight & Thanotephorus cucumeris & Major \\
\hline 3 & Sheath rot & Acrocylindrium oryzae & Major \\
\hline 4 & False smut & Ustilaginoidea virens & Minor \\
\hline 5 & Brown leaf spot & Helminthosporium oryzae & Minor \\
\hline 6 & $\begin{array}{c}\text { Narrow brown } \\
\text { spot }\end{array}$ & Cercospora oryzae & Minor \\
\hline 7 & Leaf scald & Rhynchosporium oryzae & Minor \\
\hline 8 & Stem rot & Sclerotium oryzae & Minor \\
\hline 9 & Damping off & Fusarium spp. & Minor \\
\hline 10 & Seeding blight & Helminthosporium spp. & Minor \\
\hline 11 & Stack burn & Trichoconis padwickii & Reported \\
\hline 12 & Leaf spot & Curvularia oryzae & Reported \\
\hline 13 & Black kernel & Nigrospora oryzae Hadson & Reported \\
\hline 14 & $\begin{array}{l}\text { Red blotch of } \\
\text { grain }\end{array}$ & Epicoccum purperescens & Reported \\
\hline 15 & $\begin{array}{l}\text { Gray mold of } \\
\text { grain }\end{array}$ & Cladosporium spp. & Reported \\
\hline \multicolumn{4}{|c|}{ Bacterial } \\
\hline 16 & $\begin{array}{c}\text { Bacterial leaf } \\
\text { blight }\end{array}$ & $\begin{array}{c}\text { Xanthomonas campestris pv. } \\
\text { Oryzae }\end{array}$ & Major \\
\hline 17 & $\begin{array}{l}\text { Bacterial leaf } \\
\text { streak }\end{array}$ & $\begin{array}{c}\text { Xanthomonas campestris } \\
\text { pv. oryzae translucens / f. sp. } \\
\text { Oryzicola }\end{array}$ & Major \\
\hline \multicolumn{4}{|c|}{ Nematode } \\
\hline 18 & White tip & Aphelenchoides besseyi & Minor \\
\hline \multicolumn{4}{|c|}{ Virus } \\
\hline 19 & $\begin{array}{l}\text { Rice dwarf } \\
\quad \text { virus }\end{array}$ & & Reported \\
\hline 20 & $\begin{array}{l}\text { Rice tungro } \\
\text { virus }\end{array}$ & & Reported \\
\hline \multicolumn{4}{|c|}{ Physiological } \\
\hline 21 & $\begin{array}{l}\text { Khaira (Zinc } \\
\text { deficiency) }\end{array}$ & & Minor \\
\hline
\end{tabular}

Table 1: List of Popular rice diseases common in Nepal. Source: (Amatya and Manandhar, 1985).

\section{Origin and Distribution of Pathogens}

Rice false smut (RFS), caused by the Clavicipitaceous fungus Ustilaginoidea virens, commonly known as Villosiclava virens, has now globally recognized as one of the most severe rice diseases in the majority of rice-cultivating regions (Ladhalakshmi, Laha, Singh, 
Karthikeyan, Mangrauthia, and Sundaram M, 2012). This disease was first identified in Tirunelveli district of Tamil Nadu State, India and previously tagged as a minor disease owing to its sporadic distribution. Nevertheless, the disease has spread expeditiously in major rice growing region because of extensive planting of high-yield rice cultivars and hybrids, inappropriate application of nitrogenous fertilizer and global warming in the past two decades, and has been found in about one third of rice cultivation areas $[21,25]$. The occurrence of false smut caused by Ustilaginoidea virens has been recorded from almost all the rice producing nations in the world including Australia, Italy, Bangladesh, Philippines, Peru, Myanmar, Fiji, China, Columbia, Japan, Thailand, USA, Bolivia, Brazil, Srilanka, Ghana, Indonesia, Ivory coast, Panama, Nigeria, Pakistan, an, Sudan, Tanzania, Trinidad, Venezuela, Vietnam, Zambia, [17] and in some American, Italian and Southern Asian rice-growing regions [37].

\section{Classification}

Kingdom: Fungi

Division: Ascomycota

Class: Sordariomycetes

Order: Hypocreales

Family: Clavicipitaceae

Genus: Villosiclava

Species: virens.

Favorable conditions for the false smut development

Rice is susceptible to False Smut disease only in favorable environmental and suitable grown condition. Table 2 highlights the conditions for the False Smut development in Rice.

\begin{tabular}{|c|c|}
\hline S.N & Conditions that favor False Smut development \\
\hline 1 & Presence of heavy rainfall and high humidity $(>95 \%)$ \\
\hline 2 & Presence of soils with high nitrogen content \\
\hline 3 & $\begin{array}{c}\text { Presence of wind for dissemination of the spores from } \\
\text { plant to plant }\end{array}$ \\
\hline 4 & $\begin{array}{c}\text { Presence of overwintering fungus as sclerotia and chla- } \\
\text { mydospores }\end{array}$ \\
\hline 5 & Flowering stage of the rice crop \\
\hline 6 & Temperature ranging from 25-35 degree Celsius \\
\hline
\end{tabular}

Table 2: Favorable conditions for the False Smut development.

\section{Pest identification}

Identification of false smut is very easy. Chlamydospore assembled on the spore balls are carried laterally on small sterigmata on radial hyphae, and are spherical to elliptical, warty, and olivaceous, 3 - 5 x 4 - $6 \mu \mathrm{m}$ [4]. Younger spores are tiny, paler, and almost smooth. Several green spore balls produce one to four sclerotia in the center. In more cold regions, the fungus survives the winter by means of sclerotia as well as chlamydospores. Smut ball appears like a small ball formed by using cow dung. The color is black when it is seen from a distant. In majority of the cases, not all spikelets of a panicle are damaged, but spikelets neighboring smut balls are mainly unfilled [36]. Each rice grain turned into a mass of velvety spores or yellow fruiting bodies which encloses the floral parts. Immature spores become flat to some extent and then covered by a membrane. The membrane gets broken due to the growth of the spores. Mature spores become orange in color and finally turn greenish black.

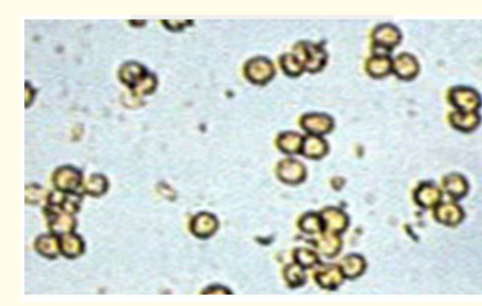

Figure 2: False smut spores.

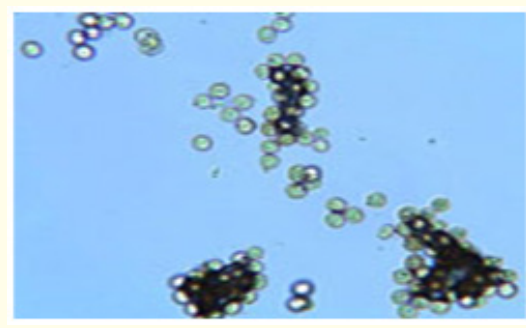

Figure 3: Microscopic view of spores.

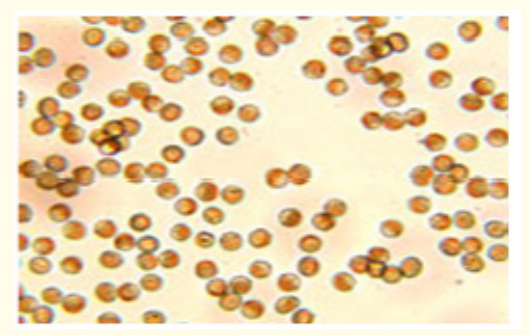

Figure 3a: Ustilaginoidea virens spores from infected rice grain. 


\section{Symptoms}

Rice False smut disease, also known as Green smut, is often known as symbol of bumper harvest. Replacement of paddy grains by ball-shaped fungal mycelia, called as false smut balls is the only visible symptom. In maturation, the false smut ball is filled with powdery chlamydospores and the colour turns to yellowish, yellowish orange, green, olive green and, finally, to greenish black [18]. Sclerotia are usually produced on the false smut balls in autumn. Although the pathogens infect rice at the time of panicle development, the symptoms are seen only after flowering. Then the spikelet are covered by the fungus. All grains convert into yellowish smut ball then changes to yellowish orange to green and greenish black on maturity. Powdery dark green spores are produced when smut balls burst open [8]. False smut leaves a direct impact on grain yield and quality through partial or complete substitute of kernels with spore masses [46].

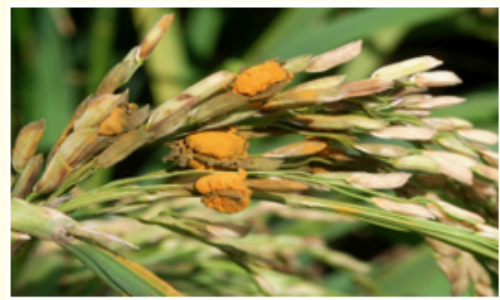

Figure 4: Greenish Black Smut Balls with a velvety appearance.

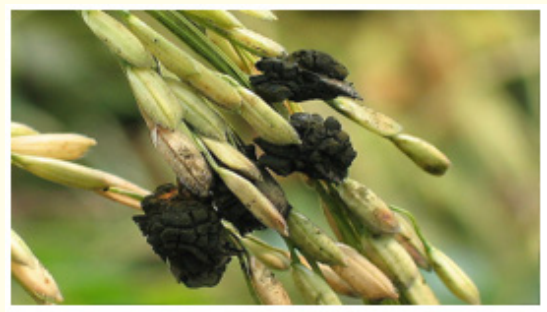

Figure 5: Smut balls bursts and becomes Black in Color.

\section{Historical yield losses due to false smut}

Aside from huge yield losses (up to $40 \%$ in severe years) caused by RFS, U. virens produces abundant amounts of mycotoxins that often contaminate rice products and are poisonous to both human and animals [49]. Due to the economic importance of the disease, many studies have been performed on the occurrence, pathogen detection, mycotoxin identification, infection lifecycle and chemi- cal control of the disease [48]. This disease is largely uninvestigated due to a historical emphasis placed on major diseases, such as blast and bacterial blight. Moreover, the label of "minor disease" for smuts environmental variability, and length of time required to rate these intractable adult plant diseases has led to a general lack of progress towards disease control [11].

\begin{tabular}{|l|c|c|}
\hline Region & $\begin{array}{c}\text { Yield loss/Extent of } \\
\text { infection (\%) }\end{array}$ & Reference \\
\hline Columbia & 20 & (FAOa, 1952) \\
\hline Peru & $>25$ & (Revilla, 1955) \\
\hline Fiji & 10 & (Morwood, 1956) \\
\hline Bangladesh & $50.3-75.4$ & (Li., et al. 1986) \\
\hline Uttar pradesh & $0.2-44.4$ & $\begin{array}{c}\text { (Singh and Dube., } \\
\text { 1978) }\end{array}$ \\
\hline $\begin{array}{l}\text { India } \\
\text { Madhya } \\
\text { pradesh }\end{array}$ & $10-30$ & $\begin{array}{c}\text { (Singh, Singh, and } \\
\text { Singh, 1987) }\end{array}$ \\
\hline India & $7.6-75.4$ & $\begin{array}{c}\text { (Agarwal and Verma, } \\
\text { 1978) }\end{array}$ \\
\hline $\begin{array}{l}\text { Andaman } \\
\text { and nicobar } \\
\text { islands, Port } \\
\text { Blair }\end{array}$ & $0.25-46.6$ & (Agarwal K 1990) \\
\hline Punjab, India & $0.04-49.0$ & $\begin{array}{c}\text { (Ansari, Ram and } \\
\text { Sharma, 1988) }\end{array}$ \\
\hline $\begin{array}{l}\text { Haryana, } \\
\text { India }\end{array}$ & $18-0$ - & $\begin{array}{c}\text { (Patel, Vala, Mehta, } \\
\text { and Patel, 1992) }\end{array}$ \\
\hline $\begin{array}{l}\text { Gujarat, India } \\
\text { (Dhindsa 1990) }\end{array}$ \\
\hline
\end{tabular}

Table 3: Historical yield losses due to false smut.

\section{Disease management}

Reduction in the disease severity relies upon the integrated approach of disease management. It starts with the seed selection including proper cultural methods and selection of effective control agent for preventing and controlling the disease. Optimum consideration of preventive and control approaches in respective time will help improve the yield by reducing disease infestation.

\section{Preventive approaches}

\section{Developing resistance varieties}

The differences in smut incidence and severity of the disease on cultivars planted in the same site or localities do occur [28,32]. Reduced levels of infection have been observed in a number of cul- 
tivars $[9,44]$. A large number of rice varieties have been reported to be resistant or tolerant by various workers based on their reaction under natural condition in fields [17]. Screening of 125 rice genotypes by artificial inoculation of false smut Kaur., et al. (2015) identified nine hybrids namely Hybrids VNR-211, GK-5025, HRI140, IRH-74, PRSH-9018, KPH-467, RH-10428, 27P64 and KRH-4 which shown complete resistance to rice false smut [24].

\section{Cultural methods}

A research conducted in United states showed that the combination of crop rotation, soil tillage, fertility rate, several alternative crop management practices were identified to provided effective control of smuts in susceptible rice cultivars [10]. Previously those same researchers had found that the moderate application of nitrogen fertility rates reduced false smut disease in susceptible cultivars [9]. Early transplanted rice had higher disease incidence when compared to late planting [12]. To escape severe damage, sowing date and heading period could be planned in such a way that flowering should not coincide with rainy period. Use of sclerotic free seeds for sowing and cleaning of bunds may help the farmers to reduce the initial occurrence of the disease.

\section{Control approaches}

\section{Chemical method}

Evaluation of fungicides Triûoxystrobin 25\%+ tebuconazole $50 \%$ and propiconazole $25 \mathrm{EC}$ in vitro and in vivo condition showed $100 \%$ inhibition to growth of fungal mycelium. Application of prochloraz + carbendazim followed by chlorothalonil was effective in controlling the false smut of rice [29]. In a study conducted in 2016 kharif nine fungicides of the present time were evaluated against the false smut disease of rice. Among the different fungicides tested azoxystrobin (18.2\%) SC + Difenconozole (11.4\%) SC and Metiram (55\%) WG + Pyraclostrobin (5\%) WG @ 0.1 per cent recorded the least disease severity of 1.85 and 2.52 per cent respectively, followed by Propiconazole 25 EC, Azoxystrobin 25\% SC, Difenconazole 25\% EC, Tebuconozole 250 EC and Flusilazole (25\%) SE + Carbendazim (12.5\%) SE showed better efficacy at 0.1 per cent and enhanced the paddy yield under field condition [31]. Raji., et al. (2016) reported that Propiconazole 25EC (0.1\%) recorded lowest disease severity than other treatments, followed by Trifloxistrobin + Tebuconazole 75 WG when sprayed at booting or $50 \%$ panicle emergence. Higher yields were obtained by spraying of Propiconazole 25 EC at booting stage and also Trifloxystrobin + Tebuconazole $75 \mathrm{WG}$ at booting [34].

\section{Essential oils and plant extracts}

Raji., et al. (2016) studied plant extracts under in vitro against rice false smut pathogen which was considerably inhibited by bulb extract of garlic (Allium sativum), rhizome extract of turmeric (Curcuma longa), leaf extracts of lantana (Lantana camara) and bael (Aeglemarmelos), whereas plant oils of lemon grass (Cymbopogon flexuous) cinnamon (Cinnamomum zeylanicum), and palmarosa (Cymbopogon martinii) have completely inhibited the growth of $U$. virens [34].

\section{Biocontrol agents:}

Kannahi., et al. (2016) studied the antagonistic potential of 9 isolates of Trichoderma viride, Trichoderma virens, Trichoderma harzianum and Trichoderma reesei obtained from rice rhizosphere under in vitro condition and reported that all the isolates of Trichoderma have showed antagonistic activity against $U$. virens but among them isolate of $T$. viride showed maximum antagonistic potential [23]. Andargie., et al. (2017) has reported Antennariella placitae to be effective against rice false smut (Ustilaginoidea virens) both in vitro and in vivo condition [6].

\section{Conclusion and Prospect}

Rice false smut was being reported as one of the minor diseases of rice until recently as the insurgence of the disease cases were observed all across the major rice growing countries. The research works around the disease for almost a century has helped us understand about the disease in details and effective ways to lower down the disease infestation. False smut is recognized easily by its smut ball of yellow to dark green color appearance on the rice grains. These smuts are toxic to humans and can cause severe health impact. Studies shows the connection of the raining during flowering, higher nitrogen uses, poor cultural methods and susceptible variety as the inciting reasons for the disease occurrence. One could either go with chemical or without chemical application for the reduction of the disease incidence. The selection of the resistant varieties like VNR-211, GK-5025, HRI-140 etc. followed with the cultural practices like scheduling the paddy transplant to avoid the rain during reproductive stage, optimum nitrogen application and crop rotation collectively will reduce the disease occurrence organically. Meanwhile chemicals can be used to get the prompt response and they usually has higher reputation of controlling the disease.

A lot of scientific work should be reinforced in the areas of the crop development. Not all the desired paddy varieties do have the 
trait of resistivity against the paddy false smut. Most of the work in the areas has provided the methodologies to reduce down the disease to minimum level. The pathologist, agronomist and the breeder need to find out the solution for the different growing conditions. The incorporation of the resistant gene in the popular hybrid paddy will provide a huge relief to the crop growing regions. Also, the focus needs to be given on the selection of the resistant lines in case of the seed production for the organic growers. With the regional cooperation of the different agriculture scientist on the disease research will provide a localized solution for the crop growers and safe food to the consumer.

\section{Bibliography}

1. "Crops/Regions/World list/Production Quantity (pick lists), Rice (paddy), 2018". UN Food and Agriculture Organization, Corporate Statistical Database (FAOSTAT) (2020).

2. Agarwal K. In Extended summary: Proc. Intern, Symp. Rice res. New Frontiers, DRR Hyderbad. 18 (1990): 234.

3. Agarwal KC and Verma H L. "Studies on varietal reaction and losses due to false smut disease of rice". Jawahar Nehru Krishi Vishwa Vidyalaya Research Journal 12 (1978): 26-30.

4. AgriTech. Expert System for Paddy (2019).

5. Amatya P and Manandhar HK. "Virus Diseases of Rice and Legume Crops in Nepal: Status and Future Strategies". Japan International Research Center for Agricultural Science 19 (1985): 3-13.

6. Andargie M., et al. "Identification and evaluation of potential bio control fungal endophytes against Ustilaginoidea virens on rice plants". World Journal of Microbiology and Biotechnology 33.120 (2017).

7. Ansari M., et al. “Oryza”. 25 (1988): 207-209.

8. Atia M. "Rice false smut (Ustilaginoidea virens) in Egypt". Journal of Plant Disease Protection 14 (2004): 71-82.

9. Brooks SA., et al. "Effect of cultural management practices on the severity of false smut and kernel smut of rice". Plant Disease 93 (2009): 1202-1208.

10. Brooks SA., et al. "Influences from long-term crop rotation, soil tillage, and fertility on the severity of rice grain smuts". Plant Disease 95 (2011): 990-996.

11. Cartwright R., et al. "Reaction of rice cultivars/lines to false smut, stem rot, and black sheath rot disease". Arkansas Rice Research Studies (1999): 158-168.
12. Chhottaray PK. Doctor of Philosophy Thesis, Orissa University of Agriculture and Technology, Bhubaneswar, Orissa (1991) 175.

13. Cooke M. "Some extra-European fungi". Grevillea 7 (1878): 1315.

14. Dhindsa H. In: Extended Summary, Proc. Intern. Symp, Rice Res. DRR, Hyderbad (1990): 15-18.

15. Dhindsa H. Indian Phytopathology 44 (1991): 120-121.

16. Dhua U., et al. "Precise disease severity assessment for false smut disease of rice". Journal of Phytopathology 16 (2015): 931-940.

17. Dodan D and Singh R. "False smut of Rice: Present status". Agricultural Revolution 17.4 (1996): 227-240.

18. Fan J., et al. "Current understanding on Villosiclava virens, a unique flower-infecting fungus causing rice false smut disease". Molecular Plant Pathology 17.9 (2016): 1321-1330.

19. FAOa. Food and Agriculture Organization of the United Nations (1952).

20. FAOSTAT. Food and Agriculture Organization of the United Nations (2020).

21. Guo X., et al. "Progress in the study of false smut disease in rice". Journal of Agricultural Science and Technology A (2012): 1211-1217.

22. Kabir MS., et al. "Rice vision for Bangladesh: 2050 and beyond". Bangladesh Renal Journal 19 (2015): 1-18.

23. Kannahi M., et al. "Biological control on rice false smut disease using Trichoderma species". International Journal of Pure and Applied Bioscience 4.2 (2016): 311-316.

24. Kaur Y., et al. "Evaluation of rice genotypes for resistance against false smut”. Plant Disease Research 30.1 (2015): 46-49.

25. Ladhalakshmi D., et al. "Isolation and characterization of Ustilaginoidea virens and survey of false smut disease of rice in India". Phytoparasitica 40.2 (2012): 171-176.

26. Li Y., et al. "Primary studies on rice false smut". Guangdong Agricultural Sciences 4 (1986): 45-47.

27. Ludueña R., et al. "Interaction of ustiloxin A with bovine brain tubulin”. Biochemical Pharmacology 47.9 (1994): 1593-1599. 
28. Mew T W., et al. "Looking ahead in rice disease research and management". Critical Reviews in Plant Sciences 23 (2004): 103-127.

29. Mohiddin FA., et al. "Integrated disease management of false smut of rice caused by Ustilaginoidea virens". Trends in Biosciences 5.4 (2012): 301-302.

30. Morwood R. "A preliminary list of plant diseases in Fiji". Fiji Agricultural Journal 27 (1956): 51-54.

31. Muniraju KM., et al. "Novel Fungicides for the Management of False Smut Disease of Rice Caused by Ustilaginoidea virens". International Journal of Current Microbiology and Applied Sciences 6.11 (2017): 2664-2669.

32. Ou SH. "Diseases of Rice". Commonwealth Mycological Institute, Kew, England. 2 (1985): 306-311.

33. Patel K., et al. "Effect of nitrogen doses on incidence of false smut of rice". Indian Journal of Mycology and Plant Pathology 22 (1992): 260-265.

34. Raji P., et al. "Evaluation of fungicides against false smut of rice caused by Ustilaginoidea Virens". International Journal of Applied and Natural Sciences 5.2 (2016): 77-82.

35. Revilla M. Bot. Estac. Expt. Agric. La Molina, 61 (1955): 1-14.

36. Rice Knowledge Bank. Your information source for rice farming (2020).

37. Rush M., et al. "Outbreak of false smut of rice in Louisiana". Plant Disease 84.1 (2000): 100.

38. Sher Singh. Crop Resources 5 (1992): 246-248.

39. Singh AK and Singh RN. "Screening for resistance to false smut (Ustilaginoidea virens Takahashi) of rice (Oryza sativa L.)". Indian Journal of Genetics 65 (2005): 49-50.

40. Singh G P., et al. "Status of false smut (FS) of rice in eastern Uttar Pradesh, India”. IRRN 12 (1987): 28.

41. Singh R and Dube K. "Assessment of loss in seven rice cultivars due to false smut". Indian Phytopathology 31 (1978): 186-188.

42. Singh R., et al. "Status of false smut (FS) of rice in eastern Uttar Pradesh, India”. Rice Research IIRI-Newsletter 12.2 (1987): 28.

43. Smith Bruce D. The Emergence of Agriculture. Scientific American Library, A Division of HPHLP, New York (1998).
44. TeBeest DO., et al. "Infection of Rice by the False Smut Fungus, Ustilaginoidea virens". In: B.R. Wells Rice Research Studies 2010. R. J. Norman, J.F. Meullenet and K.A.K. Moldenhauer, Eds. Arkansas Agricultural Experiment Station Research Series. 591 (2011): 70-81.

45. Tripathi S., et al. "In-vitro evaluation of fungicides against Ustilaginoidea virens (Cke.) Takahashi, the incitant of false smut of rice". International Journal of Applied Agricultural Sciences 12 (2014): 379-381.

46. Webster R and Gunnell P. "Compendium of Rice Diseases". American Phytopathological Society, St. Paul, MN (1992).

47. Yoshino M and Yamamoto T. "Pathogenicity of the chlamydospores of rice false smut". Agriculture and Horticulture Tokyo, 27 (1952): 291-292.

48. Zhou Y., et al. "PCR-based specific detection of Ustilaginoidea virens and Ephelis japonica”. Journal of Phytopathology 115.9 (2000): 513-518.

49. Zhou Y., et al. "Genetic diversity of rice false smut fungus, Ustilaginoidea virens and its pronounced differentiation of populations in North China". Journal of Phytopathology 156.9 (2008): 559-564.

50. Zhou L., et al. "Chemistry and biology of mycotoxins from rice false smut pathogen". In: Melborn BJ, Greene JC, editors. Mycotoxins: Properties, Applications and Hazards. New York, NY, USA: Nova Science Publishers (2012): 109-130.

\section{Assets from publication with us}

- Prompt Acknowledgement after receiving the article

- Thorough Double blinded peer review

- Rapid Publication

- Issue of Publication Certificate

- High visibility of your Published work

Website: www.actascientific.com/

Submit Article: www.actascientific.com/submission.php

Email us: editor@actascientific.com

Contact us: +919182824667 